\title{
Supply chain liability: pushing the boundaries of the common law?
}

Authors: Carolijn Terwindt ${ }^{1}$, Sheldon Leader ${ }^{2}$, Anil Yilmaz-Vastardis $^{3}$, Jane Wright $^{4}$

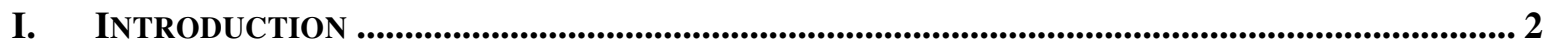

II. LEGAL DEVELOPMENTS IN THE CONTEXT OF ECONOMIC GLOBALIZATION …....................... 3

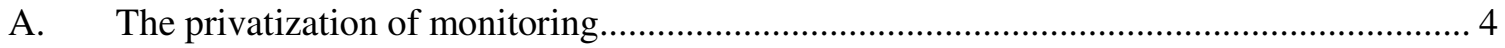

B. Going beyond voluntary monitoring: judicial routes to accountability .............................. 5

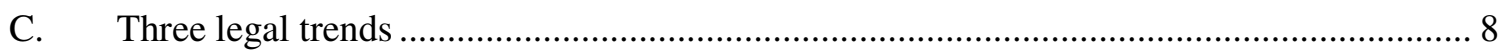

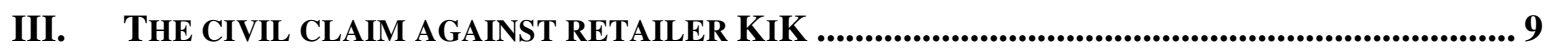

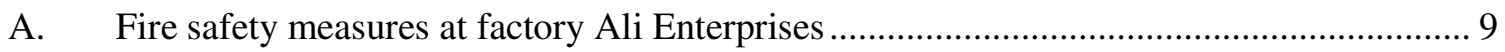

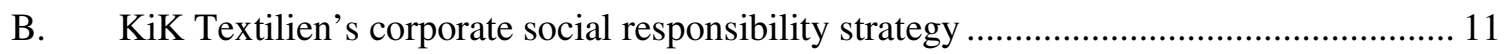

C. Jurisdiction and applicable law in the Dortmund Court .................................................. 12

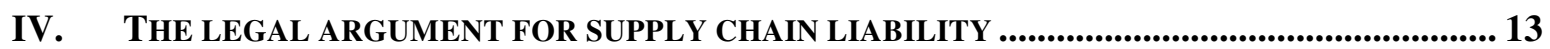

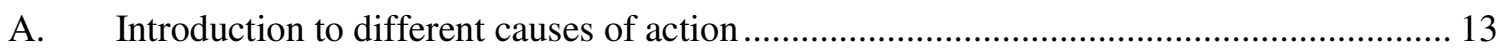

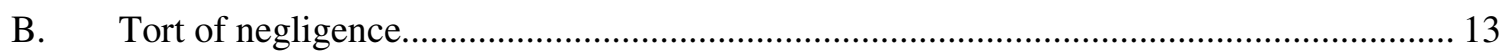

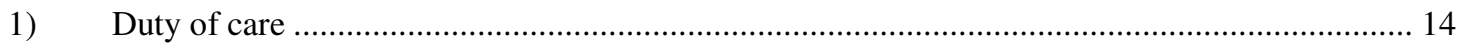

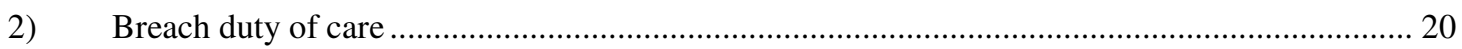

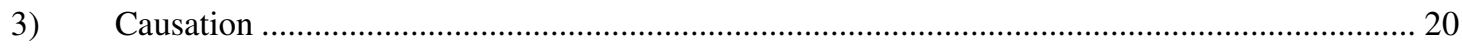

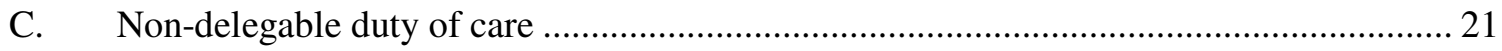

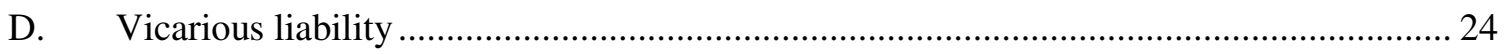

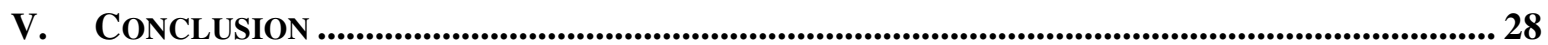

\footnotetext{
${ }^{1}$ The author is legal advisor at the European Center for Constitutional and Human Rights. She supported the Affectees Association in the preparation of the legal claim.

${ }^{2}$ Director of the Essex Business and Human Rights Project.

${ }^{3}$ Lecturer in the School of Law and Human Rights Centre at the Essex University.

${ }^{4}$ Professor of Law in the School of Law and Human Rights Centre at the University of Essex.
} 


\section{Introduction}

As soon as Muhammad Jabir heard about the fire in the factory Ali Enterprises (hereinafter AE) on 11 September 2012 in Karachi, he rushed there in order to look for his son, a machine operator. He came too late. Along with almost 300 others, his son was dead. After the first months of grieving, together with other family members, he founded the Ali Enterprises Factory Fire Affectees Association (hereinafter Affectees Association), supported by the Pakistani National Trade Union Federation. Within a year, more than two hundred survivors and family representatives of deceased workers had become members, speaking out for their rights, for adequate compensation, and the need for long-term structural change in the safety conditions in garment factories.

As the major and maybe the only buyer of the apparel produced at the factory AE, the German retailer KiK Textilien $\mathrm{GmbH}$ (hereinafter $\mathrm{KiK}$ ) started negotiations with a prominent labor organization, PILER, in Pakistan shortly after the fire. Within a few months, KiK donated one million USD into a fund to be paid out to the beneficiaries as a short-term relief. In a written agreement, $\mathrm{KiK}$ agreed to discuss its contribution to longer-term compensation. The subsequent negotiations between $\mathrm{KiK}$ and those representing the beneficiaries, however, were slow and in February 2015, the members of the Affectees Association rejected KiK's offer as it was deemed too low and without guarantee of actual payment. Instead, they decided to bring a lawsuit in Germany, where KiK is headquartered, arguing that adequate reparations for the victims is not a matter of charity, but a matter of legal liability. Mr. Jabir is one of the claimants in this lawsuit. ${ }^{5}$

On 29 August 2016, the court (Landgericht) in Dortmund, Germany, accepted jurisdiction and granted legal aid to the Pakistani claimants to cover the legal fees. ${ }^{6}$ Shortly after this significant decision, in separate negotiations, an agreement was reached in which $\mathrm{KiK}$ committed to pay 5.15 million USD to those affected by the factory fire at Ali Enterprises. ${ }^{7}$ The agreement was signed on 9 September 2016 and was the result of talks enabled by the International Labour Organization (ILO) with the German retailer KiK, IndustriALL Global Union and the Clean Clothes Campaign, on request of both the German and Pakistani government. Notwithstanding this victory, the legal claim filed in Dortmund against $\mathrm{KiK}$ continues. The legal claim asks for the symbolic payment of damages for pain and suffering, which are not covered by the ILO agreement.

\footnotetext{
${ }^{5}$ For details, see <http://www.ecchr.eu/en/our_work/business-and-human-rights/working-conditions-in-southasia/pakistan-kik.html>.

${ }^{6}$ Zeit Online, KiK muss wegen Fabrikbrand vor Gericht (30 August 2016)

$<$ http://www.zeit.de/wirtschaft/unternehmen/2016-08/schadenersatzklage-kik-pakistan-brandprozesskostenhilfe-textilfabrik>.

${ }^{7}$ International Labor Organization (ILO), Compensation arrangement agreed for victims of the Ali Enterprise factory fire in Pakistan (10 September 2016) Press Release <http://www.ilo.org/global/about-theilo/newsroom/news/WCMS_521510/lang--en/index.htm>.
} 
The case pending before the German court thus poses the question of supply chain liability. Until now, this possibility of holding buyers accountable for harms occurring in their supply chains has been discussed in academic analyses ${ }^{8}$ and in guidelines by the United Nations $(\mathrm{UN})^{9}$ and the Organization for Economic Cooperation and Development (OECD) ${ }^{10}$, but seldom in a courtroom. Taking the lawsuit by the Pakistani plaintiffs against KiK in Germany as a case study, this article provides an analysis of the available legal grounds for such liability. ${ }^{11}$ In order to provide the relevant context to the discussion, the article begins by sketching out the relevant legal developments that have taken place due to the effects of economic globalization. Economic changes have ushered in linkages between purchasers and suppliers that call for strong principles of liability - principles that are already embedded in the law but which need fresh articulation and application. This is followed by a brief description of the facts of the KiK case. The article then turns to an in-depth analysis of the possible causes of action in tort under common law ${ }^{12}$ in Jabir v KiK, in particular vicarious liability, non-delegable duty of care, and the tort of negligence. According to KiK, its practices leading to the numerous deaths were not unique to its business, but the standard industry practice. ${ }^{13}$ The outcome of the lawsuit will thus have an impact beyond this single case. The Dortmund court's decision to award legal aid to the foreign claimants already sent the signal that the possibility of supply chain liability is not without merit. ${ }^{14}$

\section{Legal developments in the context of economic globalization}

Before 1900, employers were generally not held responsible for injuries to their employees. According to legal sociologists Hoekema and Van Manen, workers led the push for a new legal understanding by bringing lawsuits against their employers. ${ }^{15}$ While the legal claims were unsuccessful, the workers managed to put the issue on the political agenda. One of the first countries in Europe to do so, in 1884 Germany enacted new legislation recognizing employers' liability for injuries occurring in the course of employment. Insurance paid for by the employer guaranteed compensation. Soon other European countries followed suit. The significance of these laws lies in the shift from fault-based liability towards risk-based obligations. Today, changes in the globalized textile industry — with widespread outsourcing and offshoring - again warrant shifts in the understanding of liability and its basis. ${ }^{16}$

\footnotetext{
${ }^{8}$ See for instance, P Rott/V Ulfbeck, Supply Chain Liability of Multinational Corporations? (2015) 3/23 European Review of Private Law (ERPL) 415-436.

${ }^{9}$ J Ruggie, Report of the Special Representative of the Secretary-General on the issue of human rights and transnational corporations and other business enterprises: Guiding Principles on Business and Human Rights: Implementing the United Nations 'Protect, Respect and Remedy’ Framework, Human Rights Council, UN-Doc. A/HRC/17/31 (21 March 2011).

${ }^{10}$ OECD Guidelines on Multinational Enterprises (2011).

${ }^{11}$ While the case inevitably also raise questions about the responsibility of auditing companies, this article focuses on the potential liability of transnational retailers.

${ }^{12}$ As the lex causae in Jabir $\mathrm{v} \mathrm{KiK}$ is the law of Pakistan, which considers English common law principles on tort as authoritative, the analysis will be limited to the principles found in those two jurisdictions.

${ }^{13}$ KiK Response to claim (26 August 2015) p 6, on file with the authors.

${ }^{14}$ Court order in the case 7 O 95/15, $7^{\text {th }}$ Zivilkammer Dortmund (29 August 2016).

${ }^{15}$ A J Hoekema/N F van Manen, Typen van legaliteit (2nd edn 2000) 133.

${ }^{16}$ Hoekema/van Manen (fn 15) 133.
} 
In response to the globalization of industrial manufacturing during the past three decades activists have called for increased responsibility of retailers for the working conditions in their supply chains. ${ }^{17}$ According to the International Trade Union Confederation, about 116 million people work in the "hidden workforce" of supply chains for 50 of the world's largest companies. ${ }^{18}$ Clearly, domestic governments and factory owners have to play an important role in creating and implementing a regulatory framework which effectively guarantees the fundamental rights of workers. Governmental inspectorates have to safeguard adherence to labor laws through regular inspections. However, under the pressures of global competition and the goal of attracting foreign investment, governments and factory owners in countries such as Pakistan and Bangladesh have not always been willing or able to ensure adequate working conditions. In response to this lack of governmental enforcement and the increasing demand for fair trade by western consumers, the 1990s and 2000s were characterized by attempts to improve working conditions through the establishment of in-house and third party monitoring mechanisms commissioned by European and North-American buyers. Retailers have increasingly drafted Codes of Conduct or adopted existing ones such as the Code of the Business Social Compliance Initiative. ${ }^{19}$

\section{A. The privatization of monitoring}

Private monitoring initiatives are premised on the assumption that in buyer-driven value chains the retailing brands "have considerable control over how, when and where manufacturing will take place, and how much profit accrues at each stage." ${ }^{20}$ Due to the highly competitive and globally decentralized producing factories, especially production of simple apparel is characterized by asymmetry and dependency between the supplier and the lead firm. ${ }^{21}$

During the past twenty years, social audits on the basis of such Codes of Conduct have, however, not been able to meaningfully improve working conditions. ${ }^{22}$ Academic research has further documented that as a stand-alone measure, without integration in the management

\footnotetext{
${ }^{17}$ G Seidman, Beyond the Boycott: Labor Rights, Human Rights, and Transnational Activism (2007); A Hale/J Wills, Women Working Worldwide: Transnational Networks, Corporate Social Responsibility and Action Research (2007) 7 Global Networks 453-476; J Hurley/D Miller, The Changing Face of the Global Garment Industry, in: A Hale/J Wills, Threads of Labour (2005) 23.

${ }^{18}$ International Trade Union Confederation (ITUC), Scandal - Inside the global supply chains of 50 top companies (2016) 6.

${ }^{19} R$ van Tulder/J van Wijk/A Kolk, From chain liability to chain responsibility (2009) 85 Journal of Business Ethics (JBE).

${ }^{20}$ G Gereffi/O Memedovic, The global apparel value chain: What prospects for upgrading by developing countries (2003) United Nations Industrial Development Organization 4.

${ }^{21}$ The apparel industry in South Asia is understood to be a so-called 'captive value chain', with low-capacity suppliers, G Gereffi/J Humphrey/T Sturgeon, The governance of global value chains (2005) 12 Review of International Political Economy (RIPE) 86-92.

${ }^{22}$ G Burckhardt, Todschick. Edle Labels, billige Mode - unmenschlich produziert (2014) 116; SOMO/Clean Clothes Campaign, Fatal Fashion (2013) 15, Human Rights Watch, Whoever Raises their Head Suffers the Most, Workers' Rights in Bangladesh's Garment Factories (2015) 60-61.
} 
structures and the presence of a trade union, codes of conducts and audits are not likely to lead to any improvements. ${ }^{23}$ Critics also argue that there is an inherent conflict of interest for auditors that are paid by the factory or brand. ${ }^{24}$ More fundamentally, the quantification and rankings produced by check-lists may even obscure a real diagnosis of working conditions. ${ }^{25}$ According to some critics, the scope and form of audits are not designed to uncover irregularities but to uphold the system of outsourcing. ${ }^{26}$ As transnational corporations have become entrusted to govern themselves, and report on their efforts to government and the public, there has been a persistent decline of state based monitoring of production processes in many countries. ${ }^{27}$

In the face of these limits of the achievements of voluntary company commitments, the catastrophes of the factory fire at Ali Enterprises in Pakistan (September 2012) and the collapse of the Rana Plaza building in Bangladesh (November 2013) have led to another response as well: the filing of lawsuits by survivors and family members demanding legal responsibility from European and North-American retailers. While in Bangladesh and Pakistan lawsuits are ongoing against owners of factories that did not provide adequate fire safety measures, against government authorities that provided invalid permits, and against inspectorates that failed to ensure proper inspections, these other lawsuits address the accountability of the retailers that outsourced manufacturing of goods sold in their outlets to these factories.

\section{B. Going beyond voluntary monitoring: judicial routes to accountability}

Previous efforts to hold companies accountable for abusive working conditions in the textile industry were limited to a few complaints at national contact points of the OECD. ${ }^{28} \mathrm{An}$ obvious obstacle to accountability has always been the lack of transparency of supply chains. ${ }^{29}$ The finding of KiK's Okay labels after the fire at AE factory fire and of many different brand labels in the rubble after the Rana Plaza collapse led to the identification of the

\footnotetext{
${ }^{23}$ RM Locke/BA Rissing/T Pal, Complements or Substitutes? Private Codes, State Regulation and the Enforcement of Labour Standards in Global Supply Chains (2013) 51 British Journal of Industrial Relations (BJIR); RM Locke/T Kochan/M Romis/F Qin, Beyond corporate codes of conduct: Work organization and Labour Standards at Nike's suppliers (2007) 146 International Labour Review (ILR).

${ }^{24}$ Locke/Kochan/Romis/Qin (fn 23) 23.

${ }^{25}$ G Le Baron/J Lister, Benchmarking global supply chains: the power of the 'ethical audit' regime (2015) 41 Review of International Studies (Rev Int Stud) 905-924.

${ }^{26}$ Ibid.

${ }^{27}$ Ibid.

${ }^{28} \mathrm{Eg}$, Clean Clothes Campaign v Adidas, filed on 5 September 2002. Most recently, in relation to the Rana Plaza collapse, Clean Clothes Campaign Denmark and Active Consumers v PWT Group, OECD National Contact Point, Denmark, final statement 2016.

${ }^{29}$ Sherpa, Supply Chain Liability. Legal tools for parent company's accountability (2007) working document. This aspect is sometimes discussed under the concept of 'traceability' the regulation of which is most advanced in relation to food and pharmaceutical drugs. See eg JE Hobbs, Liability and traceability in agri-food supply chains, in: CJM Ondersteijn/JHM Wijnands/RBM Huirne/O van Kooten (eds) Quantifying the agri-food supply chain (2006) 85-100.
} 
relevant companies that were sourcing in these factories. Such access to sourcing information has not normally been available, making it difficult to hold companies accountable. ${ }^{30}$

Though there has been a wave of lawsuits filed against parent companies for human rights harm caused by their subsidiaries, lawsuits to hold purchasers liable for harm caused by their suppliers have not been commonplace. Until now, analyses on transnational supply chain liability often addressed legal options such as tort, third-party beneficiary breach of contract or competition law in an abstract manner. ${ }^{31}$ Naturally, lawsuits can play an important role in shedding new light on existing legal concepts as previously unknown constellations of facts are presented to judges with the question whether existing legal concepts apply. This is exactly what is happening now. While in Europe a civil lawsuit was filed in 2015 against the retailer KiK for damages caused by lack of fire safety at its supplier in Pakistan, Canadian lawyers in the same year filed a claim on behalf of survivors and family members of deceased workers of two factories in the Rana Plaza building. ${ }^{32}$ Among the defendants in that claim are the retailer George Weston Ltd and its subsidiaries Loblaws and Joe Fresh as well as the auditing company Bureau Veritas. The claim is intended to be accepted as a class action, which would benefit all survivors and all dependant family members of those that died. ${ }^{33}$

Thus, in the context of these two concrete lawsuits, courts in Canada and in Germany are being asked to assess the relevant duty of care, applicable industry standards of social corporate responsibility, the relevant standards for audits, and the retailer's duty in relation to such audits. ${ }^{34}$ With their factual particularities, these lawsuits will thus contribute to the legal debate about supply chain liability by examining the concrete situation and the influence that the respective retailers had or could have had over their suppliers, the way in which a duty of

\footnotetext{
${ }^{30}$ ITUC (fn 18) 25. Notably, Nike and G-Star were early in publishing an overview of manufacturing factories. Recently, several more retailers have published their suppliers. This aspect has also received more attention from lawmakers. Eg, in March 2016, parliamentarians of the German Green Party requested the drafting of an EU Directive on transparency in the production of textiles, Antrag der Abgeordneten Renate Künast et al und der Fraktion BÜNDNIS 90/DIE GRÜNEN, Kleidung fair produzieren - EU-Richtlinie für Transparenz- und Sorgfaltspflichten in der Textilproduktion schaffen. Transparency is a major aspect, eg, of the UK Modern Slavery Act and the California Transparency in Supply Chains Act. The UK Act can even be applicable to companies incorporated outside of the UK, P Doris/M Zimmer, Ausbeutung in der Lieferkette - Der Modern Slavery Act und seine Anwendung auf deutsche Unternehmen (2016) 3 Betriebs Berater 181-183.

31 See, eg, M Saage-Maasz, Arbeitsbedingungen in der globalen Zulieferkette. Wie weit reicht die Verantwortung deutscher Unternehmen? (2011) Friedrich-Ebert-Stiftung, Internationale Politikanalyse; $E$ Kocher, Die Verantwortung von Unternehmen aus juristischer Sicht (no date) Wie weit reicht die Verantwortung von Unternehmen? Handels- und Zulieferbeziehungen von multinationalen Unternehmen, Tagungsdokumentation. D Cohen Maryanov, Sweatshop Liability: Corporate Codes of Conduct and the Governance of Labor Standards in the International Supply Chain (2011) 14 Journal of Small and Emerging Business Law 397; Y Queinnec, Supply Chain Liability. Legal tools for parent company's accountability (2007) Sherpa working document.

${ }^{32}$ New Wave Style Ltd. and New Wave Bottom Ltd.

${ }^{33}$ H Shaw, Class action suit seeks \$2 billion from Loblaw, Joe Fresh over 2013 Bangladesh garment factory collapse (30 April 2015) Financial Post.

${ }^{34}$ The causes of action argued by the plaintiffs in Canada are the tort of negligence, conspiracy and vicarious liability.
} 
care may have been breached and the way in which a relationship of vicarious liability may have come into existence. ${ }^{35}$

Similar to KiK, the Canadian defendant retailers had codes of conduct to which they pledged to adhere throughout their supply chain. A Loblaw spokesperson was reported to have said they believe the claim "is without merit" and "intend to vigorously defend our position." ${ }^{36}$ KiK has similarly expressed its determination to reject any claim of liability. ${ }^{37}$ This typical reaction raises the question whether retailers can claim that ethical working conditions are important and make public their commitment to a Code of Conduct, while at the same time refusing liability when the Code is violated. During the past decade, scholars have debated the question whether Codes of Conduct contain only moral obligations or legal ones as well. ${ }^{38}$ Regardless of any binding effect, as Rott and Ulfbeck point out, if retailers did not have any influence over their supply chains, then their Codes of Conduct and other statements on corporate social responsibility would quickly amount to misleading advertisement. ${ }^{39}$

Indeed, highlighting the discrepancy between company claims in Codes of Conduct or advertising on the one hand and the reality in supply chains on the other, has been the subject of legal proceedings in Germany (against Lidl), France (against Auchan), and the United States (against Nike). ${ }^{40}$ As Hobbs points out in relation to food safety, preventing free-riders on existing certification programs depends on an effective self-policing mechanism. The problem of such market failure is thus at least partially dependent on the ability and willingness of high quality producing firms to enforce legal protections against false or

\footnotetext{
${ }^{35}$ See, for example, the following publications which draw upon the claim against KiK,

G Wagner, Haftung für Menschenrechtsverletzungen (2016) 4/80 Rabels Zeitschrift für ausländisches und internationales Privatrecht (RabelsZ); T Thiede/ A Bell, Klagen clever kaufen! (2017) 5 Recht der Internationalen Wirtschaft (RIW); C Thomale/L Hübner, Zivilgerichtliche Durchsetzung völkerrechtlicher Unternehmensverantwortung (2017) 8 Juristenzeitung.

${ }^{36}$ CBC News, Loblaw will 'vigorously defend' lawsuit over Rana Plaza factory collapse (30 April 2015).

${ }^{37}$ Csc, Düsseldorf, KiK sieht sich nach Fabrikbrand nicht in der Haftung (2 September 2015) FAZ 21.

${ }^{38}$ A Beckers, Enforcing Corporate Social Responsibility Codes (2015); A Sobczak, Are Codes of Conduct in Global Supply Chains really voluntary? (2016) 2/16 Business Ethics Quarterly 167; C Glinski, Corporate codes of conduct: moral or legal obligation? in: DJ McBarnet, The New Corporate Accountability (2007) 133; I Schömann/A Sobczak/E Voss/P Wilke, Der Einfluss von Codes of Conduct und Internationalen Rahmenvereinbarungen auf die soziale Regulierung in Unternehmen (2008) 33.

${ }^{39} \mathrm{Rott} /$ Ulfbeck (fn 8) 422.

${ }^{40}$ For the so-called Lidl-case in Germany, see www.ecchr.eu. In France, in 2014, three French consumer and human rights organizations filed a complaint against the multinational retailer Auchan. According to the complaint, labels of Auchan products were found in the rubble at Rana Plaza. The complainants therefore argued that the ethical public statements of the brand constitute a commercial practice likely to mislead the French consumers about the social conditions of products' production. The state prosecutor in Lille, where Auchan is headquartered, opened investigation in May 2014, but decided to close it again in January 2015 on the basis that there was not enough evidence to support criminal prosecution.

'Le groupe Auchan visé par une plainte pour pratique commerciale trompeuse dans le cadre de l'effondrement du RanaPlaza', Sherpa, communiqué de presse (24 avril 2014) < http://www.asso-sherpa.org/le-groupe-auchanvise-par-plainte-pour-pratique-commerciale-trompeuse-dans-le-cadre-de-leffondrement-du-ranaplaza/\#.U4CfeVh_uNQ>.

In California, such proceedings were ongoing in the case Kasky v Nike 27 Cal $4^{\text {th }} 939$ (2002). Nike eventually decided to settle the case.
} 
misleading labeling. ${ }^{41}$ Unlike the case against $\mathrm{KiK}$ though, such proceedings are filed on behalf of competitors or consumers, not on behalf of harmed workers and their families.

\section{Three legal trends}

The step taken in the $\mathrm{KiK}$ case to bring the question of supply chain liability before judges is built on three legal developments. First, liability of a company for harms in the supply chain fits a trend of previous tort cases recognizing the possibility of parent company liability. Litigation in the United Kingdom in Chandler $v$ Cape plc has established that under certain conditions, a parent company can be liable for harms occurring at the site of its subsidiary. ${ }^{42}$ Moreover, it has been established that such liability is also possible in transnational constellations. For example, the lawsuit in the Netherlands of the Nigerian farmers Oguru, Efanga, and Dooh and the Dutch non-profit organization Milieudefensie against Royal Dutch Shell plc and Shell Petroleum Development Company Nigeria Ltd. has confirmed the possibility - in principle - of liability of the Dutch parent company for harms that occurred in Nigeria. $^{43}$

Second, the question of legal responsibility along the supply chain fits a growing recognition of the need to look beyond traditional company law concepts which restricted liability to a single company. For example, EU competition law has developed the concept of "single economic entity." On the basis of this doctrine, parent companies can be held liable for violations of EU competition rules, for the conduct of their subsidiaries, when they can be considered to form a "single undertaking" within the meaning of Article 101 of the Treaty on the Functioning of the European Union. ${ }^{44}$ The application of this doctrine has even been

\footnotetext{
${ }^{41}$ JE Hobbs, Consumer Demand for Traceability (2003) International Agricultural Trade Research Consortium 03-1 Working Paper, < http://www.iatrcweb.org/>.

${ }^{42}$ C van Dam, Tort Law and Human Rights: Brothers in Arms: On the Role of Tort Law in the Area of Business and Human Rights (2010) 3 Journal of European Tort Law (JETL); R Meeran, Tort Litigation against Multinational Corporations for Violation of Human Rights: An Overview of the Position Outside the United States (2011) 3 City University of Hong Kong Law Review (CityU LR). In a clear move away from attempts to establish liability by piercing the corporate veil, the argued basis for liability in this case was conventional tort litigation alleging direct negligence by the parent company.

${ }^{43}$ Court of Appeal The Hague (18 December 2015) ECLI:NL:GHDHA:2015:3586 (Dooh/Shell); Court of Appeal The Hague (18 December 2015) ECLI:NL:GHDHA:2015:3588 (Oguru-Efanga/Shell). There are currently no English translations of the Court of Appeal decisions. For an analysis and summary, see $C$ van Dam, Preliminary judgments Dutch Court of Appeal in the Shell Nigeria case, online available at ceesvandam.info.

${ }^{44}$ This depends on two cumulative requirements. First, it has to be demonstrated that the parent company has the potential power to direct the conduct of the subsidiary. Second, it must be shown that the parent company has actually exerted that power. Case T-587/08 Fresh Del Monte Produce, Inc., v European Commission [2013] EUECJ T-587/08 para 56 and jurisprudence cited there. If this is the case, the Commission can regard the parent company and the subsidiary as jointly and severally liable for the payment of a fine, without having to establish the personal involvement of the parent company in the infringement. Such fines can amount up to 10 per cent of the group's annual turnover. S Thomas, Guilty of a Fault that one has not committed: the Limits of the GroupBased Sanction Policy Carried out by the Commission and the European Courts in EU-Antitrust Law (2011) Journal of European Competition Law \& Practice (JECLAP). Case C-97/08 P Akzo Nobel and Others v Commission [2009] ECR I-8237 para 59; Case C-90/09 P General Química and Others v Commission [2011] ECR I-1 para 38; Case C-521/09 P Elf Aquitaine v Commission [2011] ECR I-0000 para 55.
} 
extended to circumstances beyond the relationship of a parent company and its wholly owned subsidiary. ${ }^{45}$

Third, in the area of business and human rights, lawsuits addressing supply chain liability fit a longer trend in which multilateral declarations have paved the way for recognizing responsibility of business enterprises along their supply chain, such as the latest update of the OECD Guidelines for Multinational Enterprises (2011) and the endorsement of the United Nations Guiding Principles on Business and Human Rights in that same year. For example, the responsibility to undertake due diligence to "identify, prevent, and mitigate" potential adverse impacts is recognized also for entities along the supply chain. ${ }^{46}$ This could in turn result in purchasers assuming a duty of care in tort to individuals whose human rights have been harmed by their suppliers. ${ }^{47}$

\section{The civil claim against retailer $\mathrm{KiK}^{48}$}

\section{A. Fire safety measures at factory Ali Enterprises}

On 11 September 2012 at around 6 pm, a fire broke out at Ali Enterprises factory in Karachi, Pakistan. According to a Report by the Health Department of Sindh, 262 deaths were officially registered by the surrounding three hospitals as well as an unclear number of injured persons. ${ }^{49}$ The workers died of the burns as well as of smoke inhalation and some who were trapped in the basement were boiled in the water utilized to extinguish the fire. Ali Enterprises is a private company established in 2000 and owned by a father and his two sons, one of whom is the CEO ${ }^{50}$ The factory premises consisted of three buildings: Block A, Block B and Block $\mathrm{C}$. The fire predominantly affected the three-story Block A, the factory's main building which was completely destroyed.

\footnotetext{
${ }^{45}$ Economic entities have also been deemed to exist between joint ventures and its parents, companies and nonaffiliated sales agents and between partnerships where the same natural persons are involved as partners. 
While the cause of the fire is disputed, the alleged lack of adequate fire safety measures is at the heart of the lawsuit. According to a trade union, the high number of deaths and injuries, particularly in the basement and the second floor of Block A, could in particular be traced back to the heavy iron bars on the windows and the lack of emergency exits, while the few available exits were locked, although KiK denies the lack of sufficient emergency exits. ${ }^{51}$ Some survivors reported needing at least ten minutes to break the windows while smashing them with two people using heavy machinery in order to escape the building. ${ }^{52}$ A further problem reported was the absence of fire alarms within the warehouse, due to which there was a delay before the fire was detected. ${ }^{53} \mathrm{KiK}$ denies the lack of fire alarms. ${ }^{54}$ According to statements by former factory workers there were not enough fire extinguishers and those that were there were not in working order, although this is denied by $\mathrm{KiK} .{ }^{55}$ In addition, the workers had not been trained to operate the fire extinguisher and thus were not prepared for using it, again a claim which is rejected by $\mathrm{KiK}^{56}$ Auditing organization Social Accountability International later reported that there was no general fire safety training at the factory. ${ }^{57}$

$\mathrm{KiK}$ was the main purchaser of the textiles produced in the factory. It has publicly acknowledged purchasing $75 \%$ of the total goods produced at the factory. ${ }^{58} \mathrm{KiK}$ is the largest German textile discounter based in Bönen, Germany, founded in 1994 by Stefan Heinig and Tengelmann Holding. ${ }^{59}$ Typical for globally active retailers, KiK sources over 300 million textile articles through its global supply chain. It trades with over 500 suppliers based in countries all around the world, ${ }^{60}$ particularly in Asia, mainly in China and Bangladesh but also in Pakistan. ${ }^{61} \mathrm{KiK}$ owns over 3,200 branches in eight European countries. The KiK product range includes a brand named "Okay". Clothes of this brand, particularly jeans, were produced in the AE factory in Karachi. KiK has been buying from AE since 2007. According

\footnotetext{
${ }^{51}$ Z Khan, Mapping Conditions of the Workers of Ali Enterprises in Karachi (2012) National Trade Union Federation; KiK Response to claim (26 August 2015) pp 23-24, on file with the authors.

${ }^{52}$ Affidavit of witness AA, born 1957, helper for 5 years at Ali Enterprises (26 October 2015) on file with author; Affidavit of witness MM, born 1960, machine operator for 5 years at Ali Enterprises (26 October 2015) on file with author; SOMO/Clean Clothes Campaign, Fatal Fashion (2013).

${ }^{53}$ Affidavit of witness MZ, 25 years old, machine operator at Ali Enterprises for about 4 years (26 October 2015) on file with author.

${ }^{54}$ KiK Response to claim (26 August 2015) p 24, on file with the authors.

${ }^{55}$ Z Khan (fn 50); KiK Response to claim (26 August 2015) p 24, on file with the authors.

${ }^{56}$ Affidavit of witness SA, worker at Ali Enterprises for 4 years (26 October 2015) on file with author; KiK Response to claim (26 August 2015) p 24, on file with the authors.

${ }^{57}$ Social Accountability International (SAI), Report Addendum: Fire Safety in Pakistan and Worldwide (undated).

${ }^{58}$ Statement of Michael Arretz, then KiK's Managing Director for Corporate Social Responsibility and Corporate Communication, cited in: H Kazim/N Klawitter, Zuverlässiger Lieferant (22 October 2012) 43/2012 Der Spiegel.

${ }^{59}$ KiK Textilien and Non-Food GmbH, Zahlen-Daten-Fakten (undated) <http://www.kiktextilien.com/unternehmen/fileadmin/user_upload_de/Kategorien/Presse/Zahlen-Daten-FaktenKiK_Juli\%202012.pdf>.

${ }^{60}$ Csc (fn 37).

${ }^{61}$ KiK Textilien, Lieferanten <http://www.kik-textilien.com/unternehmen/verantwortung/lieferanten/>.
} 
to statements made by former KiK Managing, Dr. Michael Arretz, the AE factory "grew big" through its business with $\mathrm{KiK}^{62}$

\title{
B. KiK Textilien's corporate social responsibility strategy
}

According to its Sustainability Report of 2010, KiK puts orders to its suppliers through forms that contain details on the description, specification and volume of goods, delivery and shipping agreements as well as price and payment conditions. Along with the order form the supplier is sent the general purchase conditions, which is signed by the supplier, and emphasizes that the use of child labor, silica gel and sandblasters in the production of the goods is not permitted. ${ }^{63}$ Since 2006, KiK has its own Code of Conduct, which all suppliers had to sign as well. The general terms and conditions rest upon the Code of Conduct, which is described as the "basis for the working relationship." ${ }^{64}$ According to KiK's Code of Conduct, its violation can lead to termination of business. ${ }^{65}$ Furthermore, the Code claims that any standard violation which is revealed to $\mathrm{KiK}$ will be sanctioned within the scope of its influence. ${ }^{66}$ This strong influence over production conditions is reiterated in KiK's affirmation in its Sustainability Report that:

\begin{abstract}
"Like most retailers we don't operate our own factories, but work with local manufacturers and suppliers. That's why we are determined to ensure that anyone who, through their work, contributes to our success, does so in appropriate conditions and with full access to their rights. To create a binding basis for all our commercial relationships, in 2006 we developed an international Code of Conduct, aligned with SAI's recognised SA8000 standard and comparable with the BSCI code of conduct".
\end{abstract}

$\mathrm{AE}$ was what is called a first tier supplier. While the contractual relations were initially brought about through a middleman company, KiK and $\mathrm{AE}$ were in direct business contact. On behalf of KiK there have been four audits in 2007, 2009 and 2011 at AE in order to verify compliance with KiK's Code of Conduct. KiK contracted the private firm UL Responsible Sourcing Inc. to carry out these audits. ${ }^{67}$ In addition to KiK's auditing efforts, on the initiative of the factory owners, AE had been certified with the SA8000 certificate only a few weeks before the tragic fire. ${ }^{6}$

\footnotetext{
${ }^{62}$ Statement by Dr. Michael Arretz, then KiK's Managing Director for Corporate Social Responsibility and Corporate Communication, cited in: Kazim/Klawitter (fn 58).

63 KiK Textilien, Nachhaltigkeitsbericht 2010, 25-39, <http://www.kik-

textilien.com/unternehmen/fileadmin/user_upload_de/Kategorien/Verantwortung/Nachhaltigkeitsbericht/Kapitel 4_Lieferanten.pdf $>$.

${ }^{64}$ Code of Conduct, 1

${ }^{65}$ Code of Conduct, 3; KiK Textilien (fn 63) 25.

${ }^{66}$ Code of Conduct, 1.

${ }^{67}$ C Dohmen, Keine Haftungsgrundlage (2 September 2015) Süddeutsche Zeitung.

${ }^{68}$ The relevant requirements for such certification are available in the 2008 Standard Document, which lists under 'health and safety' number 3.1 the following criteria: 'The company shall provide a safe and healthy workplace environment and shall take effective steps to prevent potential accidents and injury to workers' health arising out of, associated with, or occurring in the course of work, by minimising, so far as is reasonably practicable, the causes of hazards inherent in the workplace environment, and bearing in mind the prevailing knowledge of the industry and of any specific hazards' ,Social Accountability International, SA8000 ${ }^{\circledR}$ Standard and Documents (2008) <http://www.sa-intl.org/index.cfm?fuseaction=Page.ViewPage\&PageID=937> .
} 
The lawsuit in Dortmund inevitably exposes the weakest elements of the existing systems of corporate social responsibility. In their argument for liability, the claimants refer to KiK's own claims of sustainable sourcing from its public sustainability reports, in which KiK claims to visit suppliers frequently as well as to implement corrective action plans (CAPs) on the basis of audit reports. ${ }^{69}$ The claimants conclude that KiK had knowledge of the lack of fire safety measures and the power to influence AE to implement fire safety measures. In its rejoinder to these allegations, $\mathrm{KiK}$ on the one hand insists that it had in place a system for monitoring and ensuring compliance with its own claims of corporate social responsibility. KiK confirms that suppliers were obliged to sign KiK's Code of Conduct and that it expects suppliers to abide by this Code. KiK further explains that the Code was to make clear to the suppliers how important these ethically motivated principles are. ${ }^{70}$

On the other hand, KiK points out that none of these efforts imply that it had any influence on the factory processes at $\mathrm{AE} .{ }^{71}$ In its defense, $\mathrm{KiK}$ describes its sourcing process as flexible and without formal framework contracts because of the cyclical nature of the clothing business and the changing fashion trends. ${ }^{72}$ It also argues that the topics of conversation during meetings in Karachi between staff of $\mathrm{KiK}$ and $\mathrm{AE}$ were limited to "commercial" issues, rejecting any notion of control over health and safety conditions in the factory. ${ }^{73} \mathrm{KiK}$ emphasizes that during their visits its employees at no time inspected or influenced the factory, the management or the working procedures. This was not deemed to be their task. ${ }^{74}$

\section{Jurisdiction and applicable law in the Dortmund Court}

Unlike the challenges to jurisdiction in many of the transnational cases in the courts of common law jurisdictions such as the United States, Australia and Canada under the "forum non conveniens" doctrine, the territorial jurisdiction of the court of Dortmund in Germany simply flows from KiK's place of registration (Art. 2 Section 1 together with Art. 60 Section 1 Brussels I Regulation). In accordance with Art. 4 Section 1 of Regulation (EC) No 864/2007 ("Rome II"), the law applicable in the case of extra-contractual claims is the law of the State in which the harm occurred (lex loci damni). In Jabir $v$ KiK this is the law of Pakistan. Principles of the law of tort in Pakistan are mainly derived from the English common law. As Pakistani courts consider English cases as persuasive authority particularly in tort cases, ${ }^{75}$ the arguments advanced below are based on English law.

\footnotetext{
${ }^{69}$ KiK Textilien (fn 63) 27.

${ }^{70} \mathrm{KiK}$ Response to claim (26 August 2015) p 9, on file with the authors.

${ }^{71}$ F Kolf, KiK wehrt sich gegen Klage von Brandopfern (2 September 2015) Handelsblatt, < http://www.handelsblatt.com/unternehmen/handel-konsumgueter/fabrikbrand-in-pakistan-sie-haben-mit-demleben-fuer-kleidung-von-kik-gezahlt/12263558.html>.

${ }_{72}$ KiK Response to claim, 26 August 2015, p 5, on file with the authors.

${ }^{73}$ Dohmen (fn 67).

${ }^{74}$ KiK Response to claim (26 August 2015) p 7, on file with the authors.

${ }^{75}$ M Lau, Introduction to the Pakistani Legal System, with special reference to the Law of Contract (1994) 1 Yearbook of Islamic and Middle East Law (1Y.B. Islamic \& Middle E. L.) 10.
} 


\section{IV.The legal argument for supply chain liability}

\section{A. Introduction to different causes of action}

Jabir $v$ KiK concerns the potential liability of a purchaser of goods for harm ostensibly caused by its supplier of goods to third parties, i.e. employees of AE. Making a case for KiK's liability is a challenging one, as the relationship between the purchaser and the supplier is of a contractual nature, and as such an 'arm's length' transaction on the face of it. Additionally, the victims were employed by AE, and appear to have no formal relationship with KiK. Yet, the claimants argue that $\mathrm{KiK}$ should be held liable for the injuries resulting from the fire. Three alternative grounds for liability are advanced in the claim and supported by the legal opinion submitted by the claimants: ${ }^{.7}$ (1) Breach of a direct duty of care in negligence owed by KiK to the employees of AE (2) Breach of a Non-Delegable Duty of Care owed by KIK to the employees of AE, and (3) Vicarious liability on the part of KIK for the negligence of AE. Each of these grounds is elaborated below.

The arguments for liability advanced in Jabir $v$ KiK can be extended to certain supply chain relationships, where one of the parties (supplier or the purchaser) is in a special position of influence, such that the contractual relationship between them can no longer be considered an 'arm's length' transaction. In the case of $\mathrm{KiK}$ and $\mathrm{AE}$, the relationship of influence might arise from (1) KiK's representations in its Sustainability Report and Code of Conduct that it ensures supplier compliance with minimum labour standards, including "a ban on child labour, a ban on forced labour or discrimination, maximum working hours, health and safety standards for the workplace, information and reporting standards for suppliers, as well as employees' freedom of association." (2) KiK's audit of compliance including the right and opportunity to draw up CAPs and impose sanctions on AE if the latter fails to meet the standards (3) dependence of $\mathrm{AE}$ on KiK for survival as a business, which allows KiK to use its position of power, were it to wish to, to improve working conditions. This type of purchaser-supplier relationship is analogous to those in which the courts have in the past found corporate civil liability to arise out of certain parent company-subsidiary relationships.

\section{B. Tort of negligence}

The negligence claim against $\mathrm{KiK}$ is based upon an allegation that it failed to do its share to prevent the physical harm suffered by AE employees in breach of a legal obligation to secure a healthy and safe working environment. In order to establish negligence liability, the claimants must demonstrate that (1) KiK owed them a duty of care to help procure a healthy and safe working environment, (2) KiK's omission to act amounts to a breach of this duty, and (3) a causal link exists between the omission to act and the harm suffered by the employees. ${ }^{77}$ While the principles of English common law hold that there can generally be no liability for an omission, there are significant exceptions to this principle, including situations

\footnotetext{
${ }^{76}$ On file with the authors.

${ }^{77}$ MA Jones/ AM Dugdale/M Simpson, Clerk \& Lindsell on the Law of Torts (21 ${ }^{\text {st }}$ edn 2016) ch 8.04.
} 
in which a duty arises from a relationship between the parties which gives rise to an "imposition or assumption of responsibility". ${ }^{78}$

As the type of acts or omissions giving rise to a duty of care are not limited to an exhaustive list of situations, the facts of a case are of utmost importance to determine whether a new situation can be brought within existing principles such that a duty of care will be held to exist..$^{79}$ It has been recognized in case law that categories of negligence develop incrementally and by analogy with previous cases, particularly where 'an earlier limitation is no longer logically or socially justifiable' ${ }^{80}$ Due to the lack of an English precedent which establishes that a purchaser of manufactured goods owes a duty of care in negligence towards the manufacturer's employees, alongside that of the manufacturer itself, the first challenge for the AE employees is to establish that KiK owed them a duty of care. However, as stated by Lord Toulson in Michael $^{81}$ the law of negligence is not static. Many of the decided cases that are referred to below have developed the law in explicit recognition of changed social conditions, changed commercial and industrial practice, and changed social perceptions of right and wrong. Where special circumstances of a supply chain relationship coincide with the circumstances of past negligence cases, and the changed social and commercial conditions justify imposition of responsibility, it should be possible to find a duty.

\section{1) Duty of care}

The first step to finding a duty of care is to establish that the purchaser has assumed responsibility towards the employees of $\mathrm{AE}$ to ensure a healthy and safe working environment. In order to determine whether a defendant has assumed such a responsibility towards a claimant, courts commonly employ the three stage test set out in Caparo $v$ Dickman. ${ }^{82}$ This requires the claimant to establish (i) that the harm was foreseeable; (ii) proximity of relationship between claimant and defendant; and (iii) that it is fair, just and reasonable that the law should impose a duty of a given scope on one party for the benefit of the other.

\section{a. Foreseeability and proximity}

The test of reasonable foresight and proximity was formulated by Lord Atkin in Donoghue $v$ Stevenson, ${ }^{83}$ where he stated that one "must take reasonable care to avoid acts or omissions which [one] can reasonably foresee would be likely to injure [one's] neighbour." Neighbours,

\footnotetext{
${ }^{78}$ In Smith v Littlewoods Organisation Ltd [1987] AC 241, Lord Goff identified four circumstances in which a party may become liable for an omission to act: (a) where there is a special relationship between defendant and plaintiff based on an assumption of responsibility by the defendant; (b) where there is a special relationship between the defendant and the third party based on control by the defendant; (c) where defendant is responsible for a state of danger which may [be] exploited by a third party; and (d) where the defendant is responsible for property which may be used by third party to cause damage; See also (fn 77) chs 8.50-8.54.

${ }^{79}$ Jones/Dugdale/Simpson (fn 77) ch 8-05.

${ }^{80}$ See for instance, Michael v Chief Constable of South Wales [2015] AC 1732, p. 1761.

${ }^{81}$ Ibid.

${ }^{82}$ Caparo Industries plc v Dickman [1990] 2 AC 605.

${ }^{83}$ Donoghue v Stevenson [1932] AC 562, p.580.
} 
in this context, would include those that are "so closely and directly affected" by the act or omission that the defendant must have had them within his/her reasonable contemplation. To assess proximity in Jabir $v \mathrm{KiK}$, the court would ask whether the AE employees were closely and directly affected by KiK's conduct in regards to the health and safety conditions in the factory, and so should have been within the reasonable contemplation of KiK. Drilling down further to assess the foreseeability of the harm, the court would consider the knowledge that a person in KiK's position would be expected to possess in relation to the injuries suffered by the employees resulting from the fire. ${ }^{84}$

Purchasers like KiK often give specific and detailed instructions to their suppliers not only in relation to product specifications, but also in relation to the manner in which the goods are produced. ${ }^{85}$ The latter includes the Code of Conduct type documents that are incorporated into basic terms and conditions of business with suppliers. As outlined above, KiK's Code of Conduct contains requirements, inter alia, on the health and safety of workers employed at the factory. Inclusion of requirements on health and safety in contracts with suppliers and following these up through audits and CAPs, as well as the public statements by KiK about their commitment to ensuring appropriate work conditions throughout their supply chain might be considered sufficient proof that injuries suffered by the AE employees due to lack of fire safety measures at the factory were reasonably foreseeable by KiK. These coupled with the fact that there was a history of fires at the factory could reasonably be viewed as rendering the occurrence of further fires and physical injury that may result from lack of safety measures highly foreseeable.

The requirement for proximity of relationship will be fulfilled where it can be shown that the defendant has assumed responsibility to the claimant. ${ }^{86}$ This was described by Deane J. in Sutherland Shire Council v Heyman as "an assumption by one party of a responsibility to take care to avoid or prevent injury, loss or damage to the person or property of another or reliance by one party upon such care being taken where the other party ought to have known of such reliance." In those cases which conclude that a voluntary assumption of responsibility has been recognized, the finding has been that the defendant has so conducted him/herself that the claimant is entitled to rely upon the defendant in relation to the subject matter of the duty created. Furthermore, decided cases establish that where a defendant has effective control over an activity, then a duty of care may be recognized in relation to aspects of that activity. ${ }^{87}$

\footnotetext{
${ }^{84}$ Jones/Dugdale/Simpson (fn 77) ch 8-16.

${ }^{85}$ This is confirmed by KiK in its Sustainability Report 2010, p 13 that 'As a retailer that imports its products directly, we initiate, organise and oversee the flow of goods between Asian production sites and our stores in Europe. We commission the manufacture and production of goods, organise their transport and operate over 3000 stores in six European countries. We are responsible for more than 20,000 employees in Europe, people who we employ directly, as well as those workers involved in producing goods ordered by us in their respective countries. ... It is therefore logical and economically prudent for us to design processes that make the best possible use of resources, to define social and ecological standards, and adhere to them, and also to assume social responsibility above and beyond our core business activities'.

${ }^{86}$ Other indicators of proximity include physical proximity, circumstantial or causal proximity; see Sutherland Shire Council v Heyman [1985] 60 ALR 1 p. 55-56 per Deane J.

${ }^{87}$ Watson v British Board of Boxing Control [2000] EWCA Civ 2116.
} 
The primary challenge to establishing proximity between a purchaser and the employees of its supplier is overcoming the argument that a defendant, e.g. the purchaser, cannot be held liable for failing to prevent another party, e.g. AE, from inflicting damage on a third party, e.g. AE employees. The purchaser is merely in a contractual relationship with the supplier, and as such has no duty to compel the latter to secure safe working conditions in the factory. In other words, this a classic case of an omission for which there can be no liability. ${ }^{88}$ In Jabir $v$ KiK however, the relationship between $\mathrm{AE}$ and $\mathrm{KiK}$ could well be found to go beyond a mere 'arm's length' transaction. Apart from setting health and safety standards, KiK appointed auditors to inspect the factory in order to secure compliance with the Code of Conduct. KiK could be found to have had the power to compel AE to improve its safety provision by 1) its de facto ability to exert decisive pressure by ceasing to buy large amounts of output from the factory, and 2) its de jure ability to claim a breach of the Code of Conduct incorporated into the commercial contracts between it and AE. There are many factors which taken together could signify the necessary proximity of relationship/assumption of responsibility by KiK to employees of $\mathrm{AE}$ to fulfil the requirements for a duty of care.

Once an assumption of responsibility is found, there is a duty on the enterprise in the position of KiK to actively intervene to prevent the damage that occurred. The courts will look to the de facto - and not just de jure - position of power the purchaser has in relation to its supplier to determine whether the damage could be avoided if the defendant intervened to insist on a change in safety practice. The Court of Appeal (CA) in England has recently dealt with this point in Chandler $v$ Cape Industries Plc. ${ }^{89}$ In that case, a parent company was held to have a duty of care to an employee of its subsidiary, and a duty to intervene in order to fulfill that duty, where the employee had been made ill by asbestos dust on the subsidiary's premises. The Court applied the following criteria in finding a duty of care: (1) the businesses of the parent and subsidiary were in a relevant respect the same; (2) the parent had, or ought to have had, superior knowledge of some relevant aspect of health and safety in the particular industry; (3) the subsidiary's system of work was unsafe as the parent company knew, or ought to have known; and (4) the parent knew or ought to have foreseen that the subsidiary or its employees would rely on its using that superior knowledge for the employees' protection.

The CA found the parent company liable for failure to intervene to correct its subsidiary's unsafe practice even though the parent had no de jure power, simply on the basis of being the parent company, to order its subsidiary to act. It was instead a matter of seeing what, de facto, had been the policy towards health and safety adopted in the relationship between the two companies, and of seeing where the lines of influence ran, and that could vary from company to company. When and if such influence and focus on health and safety is lodged in part in the parent company then, as the Court put the point, “... at any stage it (the parent company) could have intervened and Cape Products (the subsidiary) would have bowed to its

\footnotetext{
${ }^{88}$ Sutradhar v National Environmental Research Council [2006] UKHL 33, [2006] 4 All ER 490.

${ }^{89}$ Chandler v Cape Industries Plc [2012] EWCA Civ 525.
} 
intervention. On that basis ... the Claimant has established a sufficient degree of proximity between the Defendant and himself." 90

The same could be said of $\mathrm{KiK}$ in relation to $\mathrm{AE}$, despite the fact that the latter was not a subsidiary but rather a supplier subject to the de facto and de jure power of and integrated into the links of production and sale organized by the purchasing company. Chandler is clearly distinguishable due to the lack of a corporate structure relationship between $\mathrm{KiK}$ and $\mathrm{AE}$. However, the fact that Arden LJ stated that the case has nothing to do with piercing the veil demonstrates that the corporate structure in itself is not relevant to the assumption of responsibility. A purchaser in the position of $\mathrm{KiK}$ is arguably in an analogous position to Cape Plc. because if it had made a commitment to the health and safety policy to be followed by the supplier; ${ }^{91}$ it had enough potential influence over the supplier making it able to fully implement its standards had it wished to; it had, via its auditor, specialist knowledge of the criteria for distinguishing adequate from inadequate factory safety provisions which the supplier did not have; and it was in a line of business that overlapped with that of the supplier sufficiently to make it fair that its knowledge and experience should be brought to bear on the improvements sought. ${ }^{92}$ As a company of wide experience in the sector ${ }^{93}$ KiK arguably was in a position to evaluate good practice using criteria rich in detail as compared with that available to AE alone. The joint effect of this superior knowledge of current safety criteria, taken together with its failure to intervene to rectify working conditions, could be found to have created an environment in which $\mathrm{AE}$ and its employees relied on KiK's guidance and was encouraged to continue its workplace practices due to the absence of pressure from KiK. The working environment was possibly made more dangerous due to strict deadlines set in purchase orders for production of high volume of goods. ${ }^{94}$ In such circumstances, it is possible to argue also that the pressure to meet orders led to unsafe working practices such that KiK had effectively created a source of danger which may also negative the rule against liability for omissions. ${ }^{95}$

In the case of $\mathrm{KiK}$, there are a number of elements that arguably establish proximity through an assumption of responsibility for the safety of $\mathrm{AE}$ employees including control over the working environment and reliance by the employees of AE. The desire of KiK to exercise control over the working conditions in its supply chain is acknowledged in the KiK Sustainability Report 2010, as pointed out above. ${ }^{96}$ This public commitment is put into action

\footnotetext{
${ }^{90}$ per Arden LJ, para 75.

${ }^{91}$ It should also be noted that the Court in Chandler does not insist that the parent company have a monopoly over health and safety standards before responsibility arises. Even if the parent company did not decide on all aspects of health and safety policy, if it retained enough ultimate control over the relevant features of that policy this would suffice to give rise to a duty of care; Chandler v Cape Industries Plc [2011] EWHC 951 para 59.

${ }^{92}$ This corresponds to the criteria set out by the Court of Appeal (ibid at para 80).

${ }^{93} \mathrm{KiK}$ 's response to the claim, Section I (4)(a) at $\mathrm{p} 7$ on file with the authors.

${ }^{94}$ C van Dam, Tort Law and Human Rights: Brothers in Arms (2011) 3/2 JETL 252.

${ }^{95}$ Haynes $v$ Harwood [1935] $1 \mathrm{~KB} 146$.

${ }^{96}$ Sustainability Report: 'Like most retailers we don't operate our own factories, but work with local manufacturers and suppliers. That's why we are determined to ensure that anyone who, through their work, contributes to our success, does so in appropriate conditions and with full access to their rights. To create a
} 
by incorporating its Code of Conduct into each purchase order issued to suppliers, ${ }^{97}$ by conducting audits to check compliance with the Code, ${ }^{98}$ by issuing CAPs in areas of noncompliance, and finally by holding the contractual right to terminate business relationship for failure to comply with the Code..$^{99}$ The public representations coupled with the legally binding nature of a code of conduct and the auditing processes could arguably move a purchaser beyond assuming merely a moral responsibility.

Looking at the content of the Code, under the paragraph headed 'Control' it states, 'KiK strictly demands that all business partners undertake convincing efforts to reach compliance'. A strong analogy can be drawn between the conduct of KiK regarding the manufacture of clothing by $\mathrm{AE}$ and that of other bodies which apply their regulatory standards to an activity, and which have been found liable for failing to do so with due care. ${ }^{100}$ In each case, the parties have made mandatory provision for the regulation of safety of those taking part in the relevant activity, those affected have relied upon the expertise of the regulatory body and a duty of care has been established. It is not necessary for a duty of care to arise in favour of AE employees that they should have knowingly relied upon KiK, either explicitly or implicitly. English courts have been clear that they do not consider it necessary that there be conscious reliance by a claimant on the relevant body charged with a duty of care so to exercise it. ${ }^{101}$ It is enough that, "... where A advises B as to action to be taken which will directly and foreseeably affect the safety or well-being of $\mathrm{C}$, a situation of sufficient proximity exists to found a duty of care on the part of A towards C. Whether in fact such a duty arises will depend upon the facts of the individual case..." 102

The drafting of rules and regulations might seem a more abstract and distant activity than is the giving of advice, where the latter is a clear source of liability for negligence. However, English courts have made it clear that the same duty of care can attach to the failure to implement rules and regulations as it does to advice. ${ }^{103}$ This is analogous to KiK's formulation

binding basis for all our commercial relationships, in 2006 we developed an international Code of Conduct, aligned with SAI's recognised SA8000 standard and comparable with the BSCI code of conduct'.

${ }^{97}$ The Code stipulates that ${ }^{~}[\mathrm{KiK}]$ terms and conditions rest upon this code of conduct. It is the basis for our working relationship ... The supplier shall guarantee the observation and protection of these regulations"

${ }^{98}$ The Code states that for the purpose of checking compliance, KiK or an authorised third party may at any time and without prior notice inspect its suppliers' and their subcontractors' sites.

${ }^{99} \mathrm{KiK}$ response to the Claim and the Bhandari Opinion submitted by KiK on Pakistani law states (at para 11) the only legal sanction possible in the case of non-conformity with the Code of Conduct was cancellation of the order and discontinuance of the business relationship. This means that the obligation to comply with the Code was a condition (the most serious form of contract term) of each purchase order contract.

${ }^{100}$ An example the British Boxing Board of control regarding those participating in the sport of boxing in Watson.

${ }^{101}$ In Watson, Lord Phillips in discussing whether the beneficiary of a duty of care should consciously rely upon the duty bearer stated: 'I do not consider that a conscious reliance by the patient on the hospital to exercise care is an essential element in this duty of care'.

${ }^{102}$ Watson at [72].

${ }^{103}$ In Watson, Phillips LJ recognised that no case had been cited to the court where a duty of care had been established in relation to the drafting of rules and regulations by the governing body of a sport and ${ }^{\circ}$ which have governed the conduct of third parties towards the claimant. There are, however, authorities dealing with advice given to third parties that foreseeably resulted in injury to the person or property of the claimants. [The first instance judge] equated the formulation of rules and regulations with the giving of advice'. Watson at [59]. 
of binding rules in the Code of Conduct for health and safety of workers in the AE factory. In Jabir $v \mathrm{KiK}$,it is arguable that there exists a proximate relationship between the claimants and the defendant giving rise to an assumption of responsibility; while the Code of Conduct contributes to evidence the assumption of responsibility, there were other factors referred to above namely: the audits, the CAPs, visits by KiK staff all of which induced reliance by AE and its employees upon KiK, as well as the intensity of KiK's level of demand met by AE. ${ }^{104}$

b. Is it 'fair, just and reasonable' to acknowledge this duty on a purchaser of goods?

In many cases this element can be seen as the consequence of proximity of relationship. ${ }^{105}$ Recognition of a duty of care on facts such as Jabir $v$ KiK could well be viewed as promoting safer working conditions for vulnerable workers who are exposed on a daily basis to hazardous working conditions. $\mathrm{KiK}$ is a corporation with enormous global reach; it deals with over 500 suppliers and its net sales in 2013 were over US\$2 billion. ${ }^{106}$ However, as the Sustainability Report states, KiK does not manufacture anything itself; while knowing intimately all aspects of the business from production to sales, it has outsourced entirely its manufacturing to countries in which overheads are lower than they would be in Germany. Given the features of, and risks created in, that outsourcing, of which the details of Jabir $v$ $K i K$ are a central example, it would conform with the established policies of English courts to reduce those risks to the vulnerable that the duty of care encapsulates. ${ }^{107}$

Furthermore, it is important for KiK's business reputation and consumer confidence, i.e. its social license to operate, that in the sourcing of products it does not profit from exploitation of workers in less developed countries and it is for that reason that such retailers undertake obligations towards the employees of their suppliers. It is the undertaking of responsibility as evidenced by the conduct described above that reassures the consumer and fosters the consumer confidence in the products that is so vital to this type of business. Where a retailer or a brand obtains consumer goodwill from its public commitments to ensuring compliance with international minimum standards of labour throughout their supply chain and fail to live up to those commitments, it is entirely fair, just and reasonable that they should be held accountable for failings in the supply chain over which they have taken effective control.

In discussing whether it is fair, just and reasonable that a duty of care should be owed, reference is often made to the "floodgates" argument and fears of indeterminate liability. When assessing this argument, courts distinguish cases of claims for pure economic loss and

\footnotetext{
${ }^{104}$ See also, Rott/Ulfbeck (fn 8) 420 ( ${ }^{e}$...there is no doubt that the buyer can put pressure on the supplier that the supplier can only cope with by breaching the relevant safety standards and that this will also be evident to the buyer... time pressure, potentially coupled with the implied threat to find a new supplier if deadlines are not met, will be highly likely to impact on the working hours of the supplier's employees'.).

${ }^{105}$ See Chandler and Watson.

${ }^{106}$ Para 6 Bhandari opinion, on file with the authors

${ }^{107} \mathrm{See}$, for an analogous concern to use the instrument of vicarious liability to induce enterprises and other institutions to protect the vulnerable the statements by the Court of Appeal in JGE vs The Trustees of the

Portsmouth Roman Catholic Diocesan Trust [2012] EWCA Civ 938 per Ward LJ at para 47.
} 
psychiatric harm (often brought by secondary victims i.e. witnesses to shocking events), each of which are types of claim with the potential for "ripple" effects and in which courts are concerned about the "floodgates" of liability. ${ }^{108}$ Where a claim is for physical injury by a clearly limited and defined class of claimants, ${ }^{109}$ and there is no threat that the burden of liability may be disproportionate to the conduct involved, an assumption of responsibility will more readily be recognised.

\section{2) Breach duty of care}

Once it is established that a duty of care was owed by a purchaser to the employees of its supplier, it is necessary to establish that the duty was breached. The relevant duty in Jabir $v$ $K i K$ was a duty to procure a healthy and safe working environment. It could well be found that $\mathrm{KiK}$ failed to do this as manifested by the failure to do its best to ensure adequate emergency exists, adequate fire alarms and extinguishers, safe building construction and that workers received appropriate health \& safety training. The standard of care applied in English law is objective, the reasonable person. ${ }^{110}$

Where a purchaser assumes responsibility to procure a healthy and safe working environment for employees of its supplier through codes of conduct, public statements, and monitoring processes such as audit and inspection, it shall carry out the requirements of such responsibility with reasonable care. If the purchaser fails to identify, during audits and visits to the factory, the most obvious defects in health and safety, fails to follow up on CAPs and fails to impose the sanctions envisaged in the contract, it cannot be treated as acting with reasonable care. The fact that a defendant has acted in accordance with common practice is not necessarily a valid defence, if the act is dangerous. ${ }^{111}$ Barring windows, especially, in a confined and crowded working space lacking appropriate fire exits, and failure to install fire safety measures is a bad practice and therefore negligent even if the practice is a common one in the production country in which the damage occurred.

\section{3) Causation}

Having satisfied the duty of care and breach elements, the claimants must also establish causation in fact and in law. ${ }^{12}$ The first test to establish causation in fact is the well-known

\footnotetext{
${ }^{108}$ The classic example of claims that may be rejected in part due to fears of indeterminate liability are claims for pure economic loss, that is loss which is not consequential upon physical damage; see, for example the claim for lost production at a factory due to the negligent cutting of a cable in Spartan Steel and Alloys Ltd. v Martin \& Co Ltd [1973] QB 27.

${ }^{109}$ See also Wattleworth v Goodwood Road Racing Co Ltd [2004] EWHC 140, at [122] Davis J held that placing a duty of care on an association responsible for safety standards at a racing track, owned and run by another party, to track users who suffer physical injuries in racing accidents would not amount to imposing liability to an indeterminate class. The liability would simply be to those using the track in question over which the association had in practice a degree of control for safety measures.

${ }^{110}$ Articulated in Blyth v Birmingham Waterworks Co [1856] 11 Ex Ch 781 at 784 per Alderson B as follows: 'Negligence is the omission to do something which a reasonable man, guided upon those considerations which ordinarily regulate the conduct of human affairs, would do, or something which a prudent and reasonable man would not do.'; See also Jones/ Dugdale/Simpson (fn 77) ch 1-65.

${ }^{111}$ See Morris $v$ West Hartlepool Steam Navigation Co. Ltd [1956] AC 552 as per Lord Reid; (fn 77) ch 8.145.

${ }^{112}$ See Jones/Dugdale/Simpson (fn 77) ch 2 and generally.
} 
'but-for' test - if the claimants would have suffered their injuries regardless of the defendants' negligence, the negligence has not caused the claimants' loss. ${ }^{113}$ But-for causation is established on the balance of probabilities, so an event will be treated as a cause if it is more likely than not that it was a cause. Where loss of lives and physical injuries were caused by the lack of fire safety in the factory, cause of the fire is not relevant to the assessment of liability focused on here. ${ }^{114}$ The barred windows, lack of emergency exits, lack of a functioning fire alarm and fire-fighting equipment as well as lack of fire safety training meant that the claimants and others were unable to escape the fire. The claim in Jabir $v$ KiK is that death and personal injury were caused by defective health \& safety standards as a consequence of KiK's alleged failure to meet its obligations to ensure health \& safety. It is not the fire, but the inability to deal with the fire, that is the root of the claim. The focus here is not on whether $\mathrm{KiK}$ should have prevented the fire at the factory, but rather on its responsibility once that fire had broken out. Thus, in Jabir, it is not argued that KiK caused the occurrence of the fire; rather it is argued that $\mathrm{KiK}$ in breach of its duty of care failed to take appropriate steps to ensure that if a fire occurred, then appropriate health \& safety mechanisms and building construction were in place to protect those in the factory.

'Causation in law' refers to the scope of liability. The damage suffered must be a foreseeable consequence of the breach of duty, sometimes described as requiring that any damage should not be too remote a consequence of the harm. ${ }^{115}$ The injuries suffered in Jabir $v$ KiK are the readily foreseeable consequence of the negligence and would therefore fulfil this requirement. The next question is whether or not the precautionary measures to deal with the consequences of the fire were adequate. The locking of the fire exits and barring of windows so clearly weakened the ability to respond to fire danger that arose that it arguably amounted to a substantial, and not just marginal, increase of the risk of death and injury that ensued. ${ }^{116}$

\section{Non-delegable duty of care}

A potential alternative ground for liability in supply chain cases is that the purchaser owed the employees of the supplier a non-delegable duty of care. A non-delegable duty of care is personal to the defendant and not vicarious. ${ }^{117}$ The policy of the law with regard to the nondelegable duty of care is to protect those who are both inherently vulnerable and highly

\footnotetext{
${ }^{113}$ Barnett v Chelsea and Kensington Hospital Management Committee [1969] 1 QB 428.

${ }^{114}$ In Jabir $v$ Kik, the defendants argued that the fire was caused by arson and those responsible for adequate safety cannot be held responsible for the consequences of an arsonist's action but only for the fires likely to be less severe stemming from normal internal defects in the factory. See the Bhandari opinion (para 80)

${ }^{115}$ Overseas Tankship (UK) Ltd v Morts Dock \& Engineering Co Ltd) [1961] AC 388.

${ }^{116}$ See Sienkiewicz v Greif(UK) Ltd [2011] UKSC 10.

${ }^{117}$ In Woodland $v$ Essex County Council [2013] UKSC 66 Baroness Hale, JSC, commented that in the one case [vicarious liability], the defendant is not liable because he has breached a duty which he owes personally to the claimant; he is liable because he has employed someone to go about his business for him and in the course of doing so that person has breached a duty owed to the claimant. In the other case [the non-delegable duty of care], the defendant is liable because he has breached a duty which he owes personally to the claimant, not because he has himself been at fault, but because his duty was to see that whoever performed the duty he owed to the claimant did so without fault'. At [33].
} 
dependent on the observance of proper standards of care by those with a significant degree of control over their lives. Thus, a classic - but not the only - example of the non-delegable duty of care is that owed by the employer to his employees. ${ }^{118}$ The number of situations in which non-delegable duties have been imposed is limited and so far the concept has not been applied in the supply chain context. It might reasonably be suggested that to argue for the recognition of non-delegable duties in supply chain relationships is overly ambitious. However, the recent decision of the English Supreme Court in Woodland v Essex County Council shows the potential scope for extending liability to protect the vulnerable where their safety is outsourced to a third party. In Jabir v KiK, claimants argued that while AE exercised physical control over employees on a day to day basis, KiK exercised an important element of control over the standards of health and safety in the workplace through the programme of standard setting, monitoring, audit and enforcement through the ultimate sanction of severing business relationships. In such cases, in order to meet the standard of care expected from it, a company in the position of $\mathrm{KiK}$ is not only expected to appoint a suitable auditor but is also expected to take adequate steps to assure itself that the auditor has carried out a suitable risk assessment. ${ }^{119}$ Careful selection of the auditor with the mission of assessing risk does not absolve the party which selected the auditor from the obligation itself to monitor the adequacy of the auditor's performance. ${ }^{120}$ The obligation to take steps to ensure adequate control of the risk is personal to the appointing party and cannot be delegated.

In Woodland v Essex County Council, Lord Sumption set out the criteria indicative of the recognition of a non-delegable duty of care: “... (1) The claimant is a patient or a child, or for some other reason is especially vulnerable or dependent on the protection of the defendant against the risk of injury. Other examples are likely to be prisoners and residents in care homes. (2) There is an antecedent relationship between the claimant and the defendant, independent of the negligent act or omission itself, (i) which places the claimant in the actual custody, charge or care of the defendant, and (ii) from which it is possible to impute to the defendant the assumption of a positive duty to protect the claimant from harm, and not just a duty to refrain from conduct which will foreseeably damage the claimant. It is characteristic of such relationships that they involve an element of control over the claimant, which varies in intensity from one situation to another,... (3) The claimant has no control over how the defendant chooses to perform those obligations, ie whether personally or through employees or through third parties. (4) The defendant has delegated to a third party some function which is an integral part of the positive duty which he has assumed towards the claimant; and the third party is exercising, for the purpose of the function thus delegated to him, the defendant's custody or care of the claimant and the element of control that goes with it. (5) The third party has been negligent not in some collateral respect but in the performance of the very function assumed by the defendant and delegated by the defendant to him".

\footnotetext{
${ }^{118}$ S Deakin et al, Markesinis and Deakin's Tort Law (7th edn 2012) 54.

${ }^{119}$ Uren v Corporate Leisure (UK) Ltd [2011] EWCA Civ 66.

${ }^{120}$ Ibid.
} 
In Jabir $v \mathrm{KiK}$, it appears that the employees were especially dependent upon the purchaser since, while the working environment was maintained by AE, it was the purchaser with its decisive voice that set the key expectations that standards governing this working environment would be met. Symptomatic of this concern was the purchaser's appointment of auditors, contracted to carry our inspections. However, this deployment of auditors is not sufficient to discharge such a purchaser's duty to secure a healthy and safe working environment. It continued to be responsible to ensure the safety of the working environment and could not legally delegate this responsibility to either to its supplier or the auditor. KiK's own account of its method of management of its supply chains indicates that it was intended that there be an ongoing involvement of KiK itself, as well as its auditors, (complementing the obligation of $\mathrm{AE}$ ) in managing several key features of the working environment of the victims.

This ongoing relationship between $\mathrm{KiK}$ and the employees of $\mathrm{AE}$ does arguably place the claimants in the care of $\mathrm{KiK}$ and required $\mathrm{KiK}$ to protect the claimant from a dangerous working environment. Control is manifested through the terms of, and threatened sanctions associated with the Code of Conduct, and the impacts on the workplace of the volume of orders, generating the hours it was necessary to work in order to meet the orders. The employees of $\mathrm{AE}$ had no control over how KiK elected to try to discharge its obligations, either itself or via its auditors and AE. KiK could well be found to have relied upon both $\mathrm{AE}$ and the auditor to discharge the health and safety functions the performance of which were necessary to protect the claimants from death and personal injury, and the auditor and $\mathrm{AE}$ could be found negligent in the discharge of the functions assigned to them. The argument is that a purchaser in the position of $\mathrm{KiK}$ has a non-delegable duty to ensure a safe working environment: a responsibility which cannot itself be relinquished by entrusting monitoring functions to an auditor and by relying on day-to-day management by the supplier. KiK could not delegate this duty and the failure of the auditors to correctly report on the deficiencies in health and safety at the factory which then allowed the factory continue production unsafely could give rise to a breach of this non-delegable duty by KiK. Its reports enabled KiK to convey to $\mathrm{AE}$, and thereby to the workforce, that $\mathrm{KiK}$ was satisfied that the requirements regarding fire safety had been met, so contributing to a false sense of security. The failures of the auditor in this regard were failures of a key part of KiK's own organization and obligation in relation to one of its suppliers. Following the requirements set out in the case of Woodland $v$ Essex County Council KiK's failure of organization in this regard damaged a particularly vulnerable set of victims in an antecedent relationship to $\mathrm{KiK}$ - the employees in the factory trapped there by blocked exists and without adequate equipment to fight the fire and smoke.

In previous decades there were objections by academic commentators to the principle of nondelegable duties, on the ground that it was rare for the initial person at fault not to have the resources to compensate victims. However, in Woodland, Baroness Hale stated that "Such arguments scarcely apply in today's world where large organisations may well outsource their 
responsibilities to much poorer and un- or under-insured contractors". ${ }^{121}$ This is a central issue of policy in this case. It is fair, just and reasonable that purchasers of goods such as KiK, which has effectively outsourced its manufacturing processes in order to reduce overheads, should be held to account for their failure to protect the vulnerable and dependent claimants. It is precisely for vulnerable people such as the claimants that the non-delegable duty has been recognised.

\section{Vicarious liability}

Vicarious liability could potentially be an alternative ground for holding liable a purchaser of manufactured goods for physical harm suffered by its supplier's employees in the workplace. In its classic form, vicarious liability is a strict liability regime under which an employer is held liable for harm caused by negligent conduct of its employee(s) in the course of employment. ${ }^{122}$ However, recognition of vicarious liability in other, analogous situations is on the move ${ }^{123}$ and many situations, previously unrecognized, now give rise to such liability. While the situations in which vicarious liability has been recognized embrace relationships with natural persons who are 'akin to employees', there is no reason of principle why such an extension could not apply to legal persons. Arguably, vicarious liability on the part of a purchaser such as KiK could be present in the following ways: ${ }^{124}$ (i) the purchaser's liability for the acts and omissions of the supplier; (ii) the purchaser's potential liability for the failures of inspection and accurate reporting by the auditors it appointed, engaged to carry out inter alia health and safety evaluation and monitoring in the supplier's factory.

Clearly, there is no formal employment relationship between the purchaser and the supplier or between the purchaser and its auditors. The supplier and the auditor would normally be treated as 'independent contractors' of the purchaser, and a purchaser will not normally be held liable for the harm caused by acts and omissions of such independent contractors. ${ }^{125}$ However, there are exceptions to this rule and a formal employment relationship is not always necessary to establish the vicarious nature liability. ${ }^{126}$

\footnotetext{
${ }^{121}$ Woodland v Essex County Council [2013] UKSC 66 at [42].

${ }^{122}$ Deakin (fn 118) 554.

${ }^{123}$ Various Claimants $v$ Catholic Welfare Society [2012] UKSC 56, [2013] 2 AC 1, per Lord Phillips [19].

${ }^{124} \mathrm{KiK}$ and AE could also arguably incur dual vicarious liability, if some of the AE employees' negligence caused harm to other employees in the factory. In Viasystems (Tyneside) Ltd v Thermal Transfer et al 2005 in which Rix LJ indicated that he was: ' ...sceptical that the doctrine of dual vicarious liability is to be wholly equated with the question of control. ... Even in the establishment of a formal employer/employee relationship, the right of control has not retained the critical significance it once did. ... I would hazard ... the view that what one is looking for is a situation where the employee in question, at any rate for relevant purposes, is so much a part of the work, business or organisation of both employers that it is just to make both employers answer for his negligence. ... [Vicarious liability] is a doctrine designed for the sake of the claimant imposing a liability incurred without fault because the employer is treated by the law as picking up the burden of an organisational or business relationship which he has undertaken for his own benefit.' (para 79).

${ }^{125}$ E McKendrick, Vicarious Liability and Independent Contractors: A Re-examination (1990) 53 Modern Law Review (MLR) 770-772.

${ }^{126}$ McKendrick (fn 124).
} 


\section{1) Purchaser's vicarious liability for the acts and omissions of its supplier}

If the relationship between a purchaser and a supplier is sufficiently like employment, this would justify assigning vicarious liability to the purchaser. Alternatively, even where the supplier is treated as an independent contractor, it might be possible to bring this within the scope of vicarious liability, if there is sufficient control and supervision of the relevant aspects of the contractor's business. ${ }^{127}$ Much will depend on the factual circumstances of each case, and on the willingness of courts to take into consideration the changing social and commercial realities that might justify broadening the scope of vicarious liability. ${ }^{128}$

It could be argued that the relationship between $\mathrm{KiK}$ and $\mathrm{AE}$ was sufficiently analogous to employment for purposes of health and safety provision at $\mathrm{AE}$ factory to attract vicarious liability. In E v. English Province of Our Lady of Charity the court referred to criteria put forward by Professor Kidner ${ }^{129}$ for assessing whether a working relationship is akin to employment as: ${ }^{130}$ (i) control by the "employer" of the "employee" in terms of whether the "employee" was under the management of and accountable to an "employer"; (ii) control by the contractor of himself (looking at how the contractor arranges its work, use of assets, and payments etc.); (iii) the organisation test (how central was the activity to the objectives of the business); (iv) the integration test (whether the activity was integrated into the organisational structure of the enterprise); and (v) the entrepreneur test (whether the person was in business on his own account). In order to determine whether there is a relationship akin to employment between KiK and AE, it is necessary look at the level of control KiK exercised over $\mathrm{AE}$ and on the integration of AE's production processes into KiK's overall organization.

Control in the sense required by imposing a duty of care on a purchaser was discussed above, and the points made there are also relevant in the context of the purchaser's vicarious liability. An additional point to discuss here is whether $\mathrm{AE}$ remained free to accept or reject the advice about improvement of standards enshrined in KiK's Code of Conduct. ${ }^{131}$ Three key features of the relationship between $\mathrm{KiK}$ and $\mathrm{AE}$ show that $\mathrm{AE}$ was not at full liberty to determine standards: i) the Code is not by itself legally binding on $\mathrm{AE}$, but gains its legal force by being incorporated as an implied term of the contracts governing production and delivery of goods by $\mathrm{AE}$; ii) the Code is further given effect via the de facto power that a purchaser in the position of KiK has; iii) the control conferred by (i) or (ii) was combined with the integration of AE's production process into KiK's overall organization to a degree sufficient to make this a relationship akin to employment.

It appears that KiK's Code of Conduct's provisions are intended to be incorporated into the contracts between KiK and its suppliers. The Code is not itself a contract but, like other sources, such as a typical collective agreement in UK employment law that has no legal effect

\footnotetext{
127 Ibid.

${ }^{128}$ On this see, $P$ Giliker, Vicarious Liability or Liability for the Acts of Others in Tort: A Comparative Perspective (2001) 2 JETL 31.

${ }^{129}$ R Kidner, Vicarious Liability: for whom should the 'employer' be liable? (1995) 15 Legal Studies 47.

130 JGE v The Portsmouth Roman Catholic Diocesan [2013] EWCA Civ 938, [2013] QB 722.

${ }^{131}$ This was argued by the defendants in Jabir v KiK.
} 
on its own but the bulk of its terms are incorporated into the contract of employment, the Code has terms capable of being incorporated into the relevant contracts. The courts in England distinguish elements of a company code that while general are i) sufficiently precise to be capable of implementation, ii) manifest an intention to create legal relations, and iii) to which further customary elements of workplace practice can add, placing on the other side of the line those terms in the Code that are no more than policy aspirations. ${ }^{132}$ There is a clear demand, in KiK's Code of Conduct, intended for incorporation into the on-going series of contracts of supply between the companies, that there will be a "safe and clean working environment," as expressed in paragraph 5 of the Code. ${ }^{133}$ A failure by AE to comply with this requirement would amount to a breach of its contractual obligation to $\mathrm{KiK}$, and the sanctions flowing from this breach are enough to confer control.

Even if AE has no formal legal obligation to comply with KiK's standards, KiK may still pressure $\mathrm{AE}$ to do so by the exercise of de facto power of control. It was on this basis that the Court of Appeal in Chandler $v$ Cape Industries found that the parent company had the requisite control over the subsidiary: control which the company was responsible for not exercising correctly. The subsidiary would have had no legal obligation to comply with the parent company's demand to take certain health and safety measures in Chandler, but would have been under significant de facto pressure to do so. ${ }^{134}$ This was enough for the Court to ground a finding of control in the requisite sense. Similarly, a supplier might be under a significant pressure to comply with the health and safety standards dictated by a purchaser in KiK's position.

The link between KiK's control over AE and AE's integration into KiK's organization of production and sale supports the vicarious liability of KiK for AE's negligence. KiK argued that its business relationships with $\mathrm{AE}$ are not stable, long-term mutual engagements, but are rather short term, flexible ones. ${ }^{135}$ In fact, the evidence points in the opposite direction: to a relationship over years in which AE played a role that was integrated into the organizational structure of the enterprise, as contemplated by element (iv) in the test referred to in Our Lady of Charity per Ward LJ. ${ }^{136}$ As KiK points out in its Sustainability Report, the mechanisms which it purports to put in place for the regulation of its relationship with all suppliers, including AE, are an integral part of its organizational steps by which it investigates, evaluates, and approves or rejects a supplier. The work done by AE in producing a core product for KiK's business on KiK's behalf is work that must, as the company claims, go through its filters designed to assure a product and production process of the requisite qualities. This is very different from a situation in which, for example, an architect might be

\footnotetext{
${ }^{132} S$ Deakin and G Morris Labour Law, (6 ${ }^{\text {th }}$ Ed. 2012 Hart) p. 293 Section 4.34

${ }^{133}$ Contrast other portions of the Code about eg redundancy policy which are not typically incorporated. See ACL Davies, Employment Law (2015) 318.

${ }^{134}$ UK Companies Act 2006, typically enables the parent company to appoint and remove directors of the subsidiary, but - unless a specific provision in the Articles of Association permit - does not give it legal power to dictate policy to the directors of the subsidiary with which the latter are under a legal obligation to comply.

${ }^{135} \mathrm{KiK}$ 's Response to the Claim, Section I (1)(b) at p 3.

${ }^{136}$ JGE v The Portsmouth Roman Catholic Diocesan Trust [2013] EWCA Civ 938.
} 
employed by $\mathrm{KiK}$ to design a new office building. If the architect does the work negligently this does not itself manifest a flaw in the organizational structure and effectiveness of KiK in carrying out its core activities. The matter is very different if the negligence appears in the process of producing goods which a purchaser claims as its own, and which it sells to the public as such: a process of production over which it has de facto control by its ability to decisively intervene in fixing both the specifications of the product and certain conditions under which it will be produced.

While extending vicarious liability to certain supply chain relationships might be a big step, where the relationship between the actors goes well beyond an arm's length transaction, this might be a justified extension, helping to bridge the gap between the law and economic realities of the $21^{\text {st }}$ century business models.

\section{2) The purchaser's potential liability for the failures of its auditors}

In Jabir $v \mathrm{KiK}$, the defendant insisted that that it was not aware of the faults in the safety provisions in the workplace having entrusted that assessment to its auditor and its reports. The question arises as to whether the appointment of an auditor would suffice to absolve a purchaser from liability. Evidence in Jabir $v$ KiK suggests that the auditor's reports about the adequacy of fire safety measures at the AE factory were inaccurate and misleading. ${ }^{137}$ As such, the reports could be found to have been an important contributor to the unwillingness of $\mathrm{AE}$ to reform its workplace practices, and to KiK's claim of ignorance of the actual defects of factory safety. ${ }^{138}$

The question arises as to whether KiK should be held vicariously liable for the damage done by these negligent assessments carried out by the auditor? ${ }^{139}$ A route to a purchaser's vicarious liability for its auditor's failures would be via principles establishing the auditor as agent of the purchaser. It is a basic principle of English law that a principal will be liable for the faults of its agent so long as the latter is acting within the scope of its actual authority. Under Pakistani law, AE could be considered the agent of KiK, the principal, on the basis of the Pakistani Contract Act. ${ }^{140}$ According to Pakistani case law, the relation of agency is created when the goods are sold on behalf of the principal and not the agent. It does not require a contract of agency to be in writing and this relationship can also be implied. ${ }^{141}$ An agent can

\footnotetext{
${ }^{137}$ This is contested by the defendant.

${ }^{138}$ Whether or not the latter claim by KiK to ignorance of the facts is accurate is a matter to be assessed on the evidence, along with an assessment of the impact of these false reports on AE's continuation of its poor practice.

${ }^{139}$ An assessment of the auditor's own liability in negligence will have to follow the guidelines provided in the case of Caparo v Dickman [1990] UKHL 2.

${ }^{140}$ Art 182 of the Pakistani Contract Act 1872 provides that 'an "agent" is a person employed to do any act for another or to represent another in dealings with third persons. The person for whom such act is done, or who is so represented is called the "principal".' In the following Pakistani cases, an agent - principal relationship was denied due to the lack of representation. Unlike the present constellation, these three cases concerned a situation where the supplier was considered to be the 'principal' and the buyer the 'agent'. Caltex Oil (Pakistan) Limited v Rehan-ud-din, PLD [1958] Lahore 63; Coca Cola Beverages Pakistan v Abdul Hameed Chaudhry [2001] YLR 568; Bolan Beverages (Pvt) Limited v Pepsico Inc and Others, PLD [2004] SC 860.

${ }^{141}$ Laxmi Ginning And Oil Mills vs Amrit Banaspati Co. Ltd. on 12 May, 1961
} 
even be someone not being paid by the principal and acting gratuitously. ${ }^{142}$ An agent is a conduit pipe or intermediary between the principal and third party with the competence to make the principal responsible to the third person. The auditor is the body exercising a duty on behalf of $\mathrm{KiK}$ in its relationship with third persons: the employees killed and injured by the fire. The auditor stands in for $\mathrm{KiK}$ in the discharge of the latter's responsibility for the monitoring function which consisted of verification of the quality of safety in the workplace. The auditor is indeed the 'conduit pipe' between KiK and the third persons, who are AE as an enterprise and its employees, given the assurance that it was KiK's obligation to deliver either by finding faults that needed to be fixed, or by giving clearance that the fire escape system was fit for purpose.

\section{Conclusion}

As mentioned in the introduction, in September 2016, KiK agreed to pay 5.15 million USD for income replacement for the injured workers and families of deceased. The lawsuit in Dortmund raises the question whether that payment is a matter of charity and voluntary social responsibility or whether it complies with an actual legal standard that obliges payment if certain objective conditions are met. In their defense, KiK representatives say: „If you are a customer at a bakery and buy a piece of bread there, you are not responsible if a day later the bakery burns down." ${ }^{143}$ In its decision granting legal aid, the court already recognized that the case is more complex than KiK's simple analogy would suggest. As demonstrated in this article, the argument for supply chain liability can be based on a combination of longstanding private law principles and recent case law that acknowledges the need to reinterpret old principles in the light of social change.

English courts have only recently recognized that under certain circumstances, liability might attach to a parent company under the tort of negligence for damage to third parties ostensibly caused by its subsidiary. The KiK case is testing the extension of such liability to certain supply chain relationships. Beyond that, the case is also testing the application of the rules on non-delegable duties and vicarious liability, which have been recently applied in other novel contexts, in the supply chain context. Even if the court disagrees with the Claimants' position, the novel arguments advanced in this case are likely to be the starting point for an important debate about the proper fit between traditional tort law and the fast changing commercial and employment relationships of the $21^{\text {st }}$ century.

Where voluntary commitments have failed to protect workers, the recognition of liability of retailers for harms occurring in their supply chain can provide the necessary incentive to ensure that safety measures are in place. A change may already be underway. Early 2016, a newspaper reported that $\mathrm{KiK}$ had initiated changes in its auditing commissioning practices, as it negotiated with audit companies for longer periods of validity of their reports, thus

\footnotetext{
${ }^{142}$ PLD 1960 Kar 484.

${ }^{143}$ C Lobenstein/ P Pinzler, Ist KiK schuld? (4 August 2016) 33 Die Zeit < http://www.zeit.de/2016/33/kiktextilindustrie-pakistan-brand-globalisierung/komplettansicht $>$.
} 
increasing the potential liability of auditors. ${ }^{144}$ Supply chain liability thus can be the key to transforming current practices to ensure better working conditions in the textile industry.

${ }^{144}$ C Dohmen, Mehr Pflichten für Prüfer (4 March 2016) Süddeutsche Zeitung, 4 March $2016<$ http://www.sueddeutsche.de/wirtschaft/textilbranche-mehr-pflichten-fuer-pruefer-1.2890388>; Barrie, Leonie, "How KiK is raising the bar on working conditions - Interview", 11 April 2017, available at: http://www.juststyle.com/interview/how-kik-is-raising-the-bar-on-working-conditions-interview_id130409.aspx. 